\title{
Geniş̧letilmiş Çelik Levhalarla Güçlendirilmiş Blok Tuğla Duvarlarda Bulon Aralığının Dayanım ve Davranış Üzerindeki Etkisi
}

\author{
Muhammet Zeki Özyurt ${ }^{1 *}$, Mohammadi Mohammadi ${ }^{2}$, Alper Cumhur ${ }^{3}$ \\ ${ }^{1}$ Sakarya Üniversitesi, Mühendislik Fakültesi, İnşaat Mühendisliği Bölümü, Sakarya, Türkiye (ORCID: 0000-0002-1593-4581) \\ ${ }^{2}$ Sakarya Üniversitesi, Fen Bilimleri Enstitüsü, İnşaat Mühendisliği Anabilim Dalı, Sakarya, Türkiye (ORCID: 0000-0003-0688-3759) \\ ${ }^{3}$ Yalova Üniversitesi, Mühendislik Fakültesi, İnşaat Mühendisliği Bölümü, Yalova, Türkiye (ORCID: 0000-0003-3664-3545)
}

(Bu yayın 26-27 Haziran 2020 tarihinde HORA-2020 kongresinde sözlü olarak sunulmuştur.)

(DOI: 10.31590/ejosat.780136)

ATIF/REFERENCE: Özyurt, M. Z., Mohammadi, M. \& Cumhur, A. (2020). Genişletilmiş Çelik Levhalarla Güçlendirilmiş Blok Tuğla Duvarlarda Bulon Aralığının Dayanım ve Davranış Üzerindeki Etkisi. Avrupa Bilim ve Teknoloji Dergisi, (Special Issue), 365-373.

\section{Öz}

Dünya genelinde meydana gelen büyük şiddetli depremler; çok sayıdaki binaların hasar görmesine neden olmuş, can ve mal kaybına yol açmıştır. Bu nedenle ileride meydana gelmesi muhtemel yeni depremlere karşı hasarlı ve kusurlu üretilmiş binaların onarım ve güçlendirilmesi önem arz etmektedir. Bu konuyla ilgili araştırmacılar tarafindan farklı güçlendirme teknikleri geliştirilmiş̧tir. Literatürde; yığma yapıların taşıyıcı duvarlarda farklı malzemeler (FRP şeritler, karbon lifli kumaş, delikli sac ve genişletilmiş çelik levha vs) ile güçlendirilmesi üzerine farklı yöntemler üzerinde durulmaktadır. Ancak, bu yöntemlerin birçoğunun maliyetlerinin çok yüksek olması, zaman alıcı ve zahmetli olması ve uygulama esnasında yapının tahliye edilmesi gibi olumsuz durumlar da söz konusu olabilmektedir. Bu çalışmada; araştırma konusu olan yığma yapılar için düşey delikli blok tuğla duvarlarının güçlendirilmesi amacıyla yerli üretim, ucuz ve sünekliği artıran genişletilmiş çelik levhaların kullanılması öngörülmüş̧ür. Bu malzeme yığma blok duvarın ön ve arka yüzüne ankrajlanarak uygulanması ile gerçekleştirilmektedir ve seri olarak uygulanabilmesi ile yığma yapının tahliyesine gerek kalmadan güçlendirilmesi mümkün olabilmektedir. Bu çalışmada; bir adet referans, 4 adet güçlendirilmiş eleman olmak üzere toplam 5 adet deney elemanı hazırlanmıştır. Numuneler, düşey diyagonal olarak tekdüze basınç yükleri altında test edilmiştir. Mevcut tuğla duvarlarının iki yüzüne genişletilmiş çelik levhalar eklenmiş ve bu levhalar duvarın iki tarafindan bulonlar ile bağlanarak duvar elemanları güçlendirilmiştir. Düşey delikli blok tuğla duvarı deney elemanlarına uygulanan bulon aralıkları deney değişkeni olarak belirlenmiştir. Yapılan deneylerin sonucunda, elemanların yük taşıma kapasitesinin, dayanımının, sünekliğinin ve rijitliğinin arttığı görülmüştür. Ayrıca deney elamanlarının deney sonuna kadar bütünlüklerini korudukları tespit edilmişsir.

Anahtar kelimeler: Yığma Yapı, düşey delikli blok tuğla, güçlendirme, genişletilmiş çelik levha, diyagonal basınç yüklemesi.

\section{The Effect of Bulbar Range on Strength and Behavior in Block Brick Walls Strengthened with Expanded Steel Sheets}

\begin{abstract}
The earthquakes that have occurred in the past caused significant damages to numerous structures around the globe, which resulted in huge economic losses and took many lives. Therefore, in order to reduce the damages of structures exposed to a likely earthquake in the future, the damaged buildings, as well as those structures built with low standard, are required to be retrofitted and repaired. In this respect, different retrofitting techniques have been developed in the literature. For what concern the retrofitting and strengthening of the masonry walls, different materials (fibrous polymer strips, carbon fiber fabric, perforated sheet and expanded steel plate etc.) was considered using different methods. However, most of the available methods require too much time and their application is too costly, also during the strengthening process, the evacuation of the buildings is mandatory which makes them less practical. In this study, it is intended to imply more economical and practical method for strengthening infill was using externally-connected expanded steel plates. In this method, the retrofitting process is fulfilled by tying the infill walls from outside therefore the evacuation of the structures is not required. The investigation is conducted by considering a total of five test specimens, where one of them is used as a reference and the other 4 are strengthened. The constructed specimens are then tested under monotonic diagonal loading. The retrofitting process simply began by attaching the expanded steel plates to both sides of the existing infill walls and these plates are then bolted to each other from both sides. It worth mentioning that the distance between the bolts is designated as the test variable. As a result, it was observed that the strengthened masonry walls with expanded steel plates behave as a composite material until the bolts reached their yielding capacities.
\end{abstract}


In addition, the retrofitted specimens maintained their integrity up to the end of the experiment and their load bearing capacities were increased. Furthermore, mechanical properties of strengthened masonry walls such as their rigidity, ductility and energy dissipation was increased significantly and accordingly their behavior have been affected positively.

Keywords: Vertical in filled brick walls with openings, rehabilitation, expanded steel plate, masonry building, monotonic diagonal loading.

\section{Giriş}

Dünyada en sık görülen doğal afetlerden biri depremdir. Yığma yapılar da betonarme veya çelik yapılar gibi deprem riskine maruz kalmaktadır. Bu felaketlerin bir sonucu olarak, binaların tamamen veya kısmen tahrip olması, büyük can ve mal kaybları meydana gelmesidir. Bu felaketlere karşı mevcut yapıların güçlendirilmesi gerekmektedir. Bununla birlikte; depreme maruz kalan yığma binanın iyileştirme ve güçlendirme çalışmaları başlamadan önce; deprem davranışı ve çökme mekanizması iyi bilinmelidir. Önleme yollarından biri, mevcut yapıları güçlendirmektir. Araştırmacılar yıllardır çeşitli iyileştirme teknikleri geliştirmekte ve bu tekniklerin üzerinde çalışmaktadırlar. Najif ve diğg. (2011), dolgu duvarların iç kayma davranışının iyileştirilmesi ile ilgili yaptıkları çalışmada; toplam 17 tane 1,2 m x 1,2 m boyutunda numune hazırlamışlardır. Daha sonra bu numunelerin yüzeyine yakın olarak monte edilmiş yüksek mukavemetli bükülmüş paslanmaz çelik kullanılarak numuneler güçlendirilmiş ve çalışmada bu donatı çubukları incelenmiştir. Numunelere tek taraflı ve iki taraflı olarak donatı numuneleri uygulanmıştır. Deneylerin sonucunda; sismik davranışla ilgili parametreler, kayma davranışı, kayma kapasitesi, süneklik, kayma modülü ve elastik modülündeki değişimler incelenmiştir. Çalışmada; en dikkat çekici iyileşmenin kayma gerilmesinde meydana geldiği görülmüş ve kayma gerilmesinin \%114- \%189 oranlarında artıtı̆̆ belirlenmiştir.

Tekeli ve diğ. (2014), yaptıkları bir çalışmada; dolgu duvarlarının yük taşıma kapasitesi ve enerji tüketme kapasitesini artırmak amacıyla biri referans olmak üzere aynı özelliklere sahip 4 adet betonarme çerçeve numune hazırlamışlardır. Tuğla dolgu numunelerin iki tanesi tek yüzeyinden, bir tanesi ise iki yüzeyinden hasır çelik donatılı özel sıva ile güçlendirilmiş olup, işçilik ve ankraj aralığı değiştirilmiştir. Deney sonucunda tek taraflı olarak güçlendirilen; seyrek ankarajlı numunede yanal yük taşıma kapasitesinin \%120 oranında arttığı, sık ankrajlı numunede ise bu oranın \%160 olarak gerçekleştiği görülmüştür. Çift taraflı güçlendirilmiş elemanlarda ise bu oran \%180 değerine ulaşmıştır. İşçiliği kötü olan numunelerde ise, hasır çelik yüzeyinin deney sırasında dolgu duvardan ayrıldığg görülmüştür.

Özbek, (2015) yılında yaptığı çalışma ile, delikli çelik levhalarla güçlendirilmiş tuğla dolgu duvarlara sahip olan betonarme çerçevelerin davranışlarını deneysel olarak incelemiştir. Bu amaçla birisi referans ve beşi delikli çelik levhalarla güçlendirilmiş eleman olmakla birlikte $1 / 2$ ölçekli toplam 6 adet deney elemanı üretilmiştir. Üretilen sıvalı tuğla duvarları, çelik profiller ve köşelerde kullanılan ince üçgen sac levhalarla takviye ederek deneyler yapılmıştır. Çalışmanın sonucunda da kullanılan üçgen levhaların, sargılama basıncını arttırdığı ve köşelerdeki tuğlaların ezilmesini önlediği görülmüştür. Üçgen levhaların boyutları ve sayısı arttıkça tuğla duvar dayanımında da artış olduğu ve dayanımın yaklaşık 3,5 kat; rijitliğin ise 3 kat arttığı görülmüştür. Cumhur tarafından, (2016) yılında yapılan çalışmada; genişletilmiş çelik levhaların dolgu duvarlar üzerindeki etkisi araştırılmıştır. Çalışma kapsamında; biri referans, olmakla birlikte toplam 30 adet bire bir ölçekli güçlendirilmiş deney elemanı üretilmiş ve köşegen boyunca tekdüze basınç yükleri altında deneyler yapılmıştır. Çalışmada genişletilmiş çelik levhanın kalınlığı, bulon ankraj aralıkları ve çelik levhanın konumu deney değişkenleri olarak belirlenmiştir. Mevcut tuğla dolgu duvarların iki yüzüne genişletilmiş çelik levhalar eklenmiş ve bu levhalar birbirlerine bulonlarla bağlanarak sabitlenerek numuneler güçlendirilmiştir. Güçlendirilmiş deney elemanların referans deney elemanlarına göre, taşıma gücünde 3,5 kat, rijitliklerinde 3,0 kat ve sünekliklerinde ise 8,5 kat artış sağladığını belirtmiştir. Ayrıca enerji dönüştürme kapasitesi referans numunelerin ortalamasına göre 5-30 katına ulaştığını. Yapılan çalışmanın sonucunda, genişletilmiş çelik levhalar ile güçlendirilmiş duvarların çekme gerilmelerinin büyük bir kısmının karşılandığı, duvar üzerinde üç eksenli sayılabilecek bir sargılama basıncının oluştuğu ve bulonlarda akma oluşuncaya kadar duvarın kompozit bir malzeme gibi davrandığı görülmüştür.

\subsection{Yığma Yapının Tanımı}

Mühendislik açısından, tüm duvarlarının taşıyıcı olduğu yapıya yığma yapı denir. Bu duvarların hasar görmesi doğrudan taşıyıcı sistemi etkiler.

Doğaltaş, tuğla, kerpiç, biriket blokların bir bağlama harcı ile birleştirilmesiyle, yatay ve düşey karakterli yüklerin duvarlara taşıtıldığı yığma yapılarda, duvarlar kendi iç dokusunda yeterli bir kenetlenme ve bağ kuvveti oluşturamadığı için yeterli rijitlik davranış sergileyemezler. Yığma yapının dayanımı, hem duvarlar ve harç arasındaki bağa hem de yığma malzemenin dayanımına bağlıdır (Bahçekapalı 2003).

Bu çalışmanın temel amacı; Yı̆ğma yapılarda taşıyıcı olan düşey delikli blok tuğla duvar deney numuneleri üretilerek genişletilmiş çelik levhalar ile güçlendirilmiş gerekli yanal rijitlik ve dayanımı sağlayıp binaya katkıda bulunarak duvarların çökme ekseninden düşmesini önlemek için düşey delikli blok tuğla duvarların davranışını iyileştirmek, böylece can ve mal güvenliğini sağlamaktır.

$\mathrm{Bu}$ kapsamda yığma (düşey delikli tuğla) duvarları genişletilmiş çelik levhalarla deprem yüklerine karşı güçlendirilmeye çalışılmıştır. Genişletilmiş çelik levhalar; yerli üretim, kolaylıkla elde edinilebilir, deliklerinden dolayı düz çeliğe göre çok daha sünek davranabilen, alternatif malzemelere göre daha ucuz, uygulamaya elverişli bir malzemedir. Sakarya üniversitesi inşaat mühendisliği bölümü yapı laboratuvarında gerçekleştirilmiş mevcut deneysel çalışmada $1 / 1$ ölçekli düşey delikli blok tuğla duvarlar genişletilmiş çelik levhalar kullanılarak güçlendirilmiştir. 
Bu çalışmada; birisi referans, birisi güçlendirilmiş deneme elemanı ve üç tanesi güçlendirilmiş düşey delikli tuğla duvarı olmak üzere, toplam beş adet $1 / 1$ ölçekli yığma duvar numunesi tekdüze diyagonal yük altında test edilmiştir. Düşey yükler yığma duvarlarda basınç gerilmeleri oluşturmaktadır. Güçlendirilmiş olan deney elemanların oluşturmak için, duvarın her iki tarafına genişletilmiş çelik levhalar uygulanmıştır. Bu çelik levhalar duvara ve birbirlerine gerilmiş çelik bulonlarla bağlanmıştır. Genişletilmiş çelik levha kalınlığı ve bulon aralıkları, deney çalışmasının değişken parametreleri olarak belirlenmiştir. Daha sonra çelik levhalar üzerinde $20 \mathrm{~mm}$ kalınlığında sıva uygulanmıştır. Deneyde oluşan hasarların gözlemlenmesi ve daha gerçekçi sonuçlar elde edilebilmesi amacı ile sıvanın üzerinde alçı sıvası da uygulanmıştır. Deney sonuçları yardımıyla; taşıma kapasitesi, süneklik, rijitlik ve enerji tüketimi değerlendirmeleri yapılmıştır. Ayrıca; deney elemanlarının ön yüzündeki ve arka yüzündeki deformasyonlar ölçülerek, duvarda meydana gelen birim uzamalar/kısalmalar değerlendirilmiştir.

\section{Deneysel Çalışma ve Yöntem}

$\mathrm{Bu}$ çalışmada, deney numunelerinin üretilmesi için Türkiye şartlarında standartlara uygun tuğlalar, sıva malzemesi ve alçı malzemesi temin edilmiştir. Düşey delikli tuğlalar $(135 \mathrm{~mm} \times 190 \mathrm{~mm} \times 290 \mathrm{~mm})$ kullanılmak suretiyle deney elemanları imal edilmiştir. Tuğlaların delikler düşey yöne gelecek şeklinde örülmüştür. Gereken malzemeleri hazırlandıktan sonra referans numunesi çelik kalıp içinde sıvalı düşey delikli tuğla duvarları örülmüsştür. Duvarlar örülürken yaklaşık $10 \mathrm{~mm}$ düşey delikli tuğlanın arasında sıva harcı ile doldurulmuştur. Duvarların yüzeyi yaklaşık $20 \mathrm{~mm}$ kalınlığında çimento-kum-kireç karışım harcı karışımı ile sıva uygulaması yapılmıştır. Güçlendirilmiş deney elemanları daha iyi ve gerçekçi sonuçlar elde etmek amacıyla bütün duvarların işçiliği aynı kişi tarafından gerçekleştirilmiş olup, duvar işçiliği sıradan bir işçilik olup hep aynı düzende örülmesi sağlanmıştır. Sıvanın en iyi şeklinde yapılmasına dikkat edilmiştir.

Tabloda deney elemanlarına verilen indislerin açılımları aşağıda verilmiştir.

a. $\quad \mathrm{R}=$ Referans Eleman

b. MBW=(Masonry Brick Wall) Yığma Tuğla Duvar

Tablo 1. Deney Elemanlarının Özellikleri

\begin{tabular}{|c|c|c|c|c|c|}
\hline Deney No & Numune & $\begin{array}{l}\text { Siva } \\
\mathrm{mm}\end{array}$ & $\begin{array}{c}\text { Levha Kalınlı̆ }{ }_{1} \\
\text { (mm) }\end{array}$ & $\begin{array}{l}\text { Bulon Aralığ } \\
\text { (mm) }\end{array}$ & $\begin{array}{c}\text { M6 Bulon } \\
\text { Sayıs1 }\end{array}$ \\
\hline 1 & $\mathrm{R}$ & 20 & - & - & - \\
\hline 2 & $\begin{array}{c}\text { MBW 2,0-200 } \\
\text { (Deneme Eleman1) }\end{array}$ & 20 & 2,0 & 200 & 25 \\
\hline 3 & MBW 3,0-100 & 20 & 3,0 & 100 & 100 \\
\hline 4 & MBW 3,0-150 & 20 & 3,0 & 150 & 49 \\
\hline 5 & MBW 3,0-200 & 20 & 3,0 & 200 & 25 \\
\hline
\end{tabular}
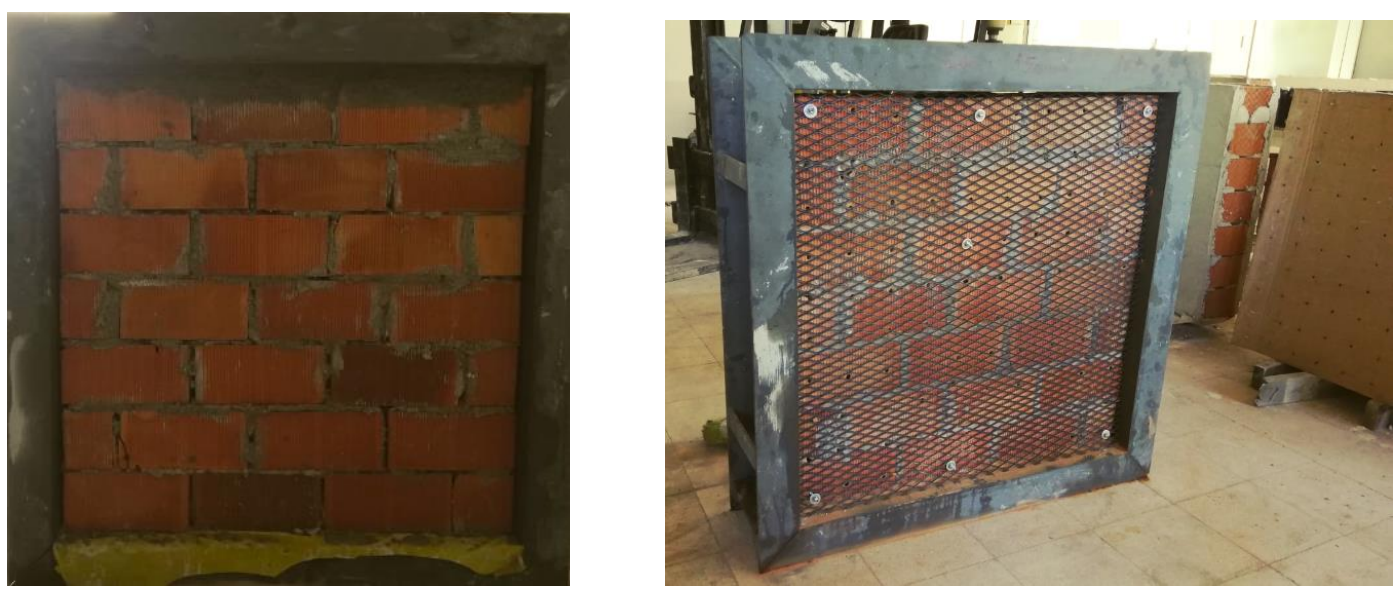

Şekil 1. Deney Elemanının Tuğla Örülme Aşaması 


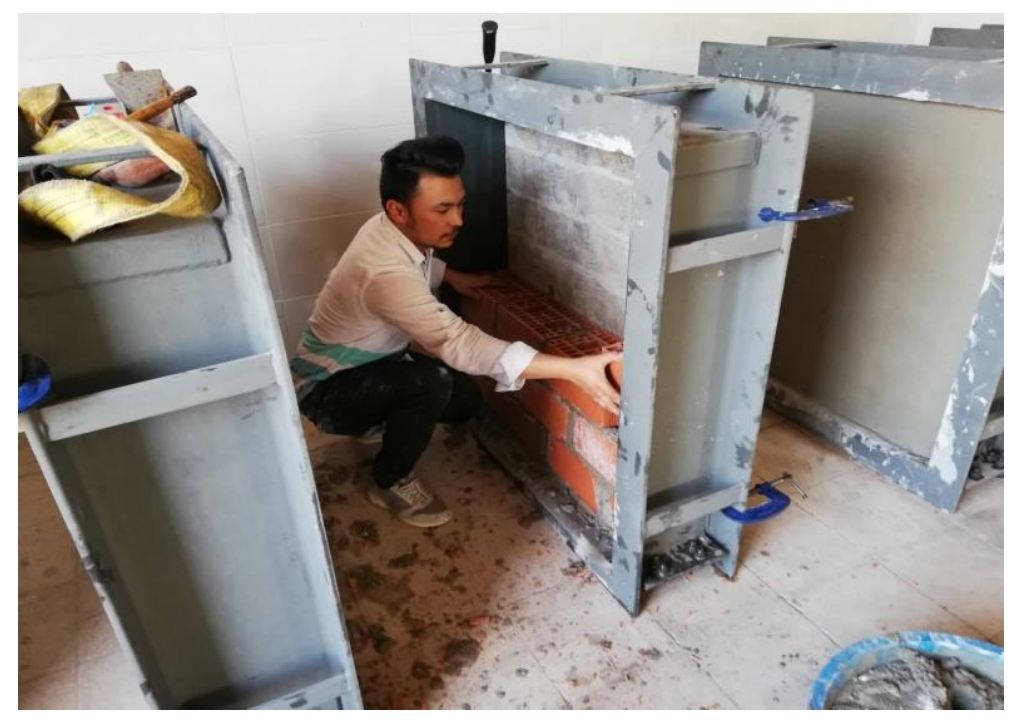

Şekil 2. Deney Elemanının 2 Ankrajlanma Aşaması

\section{Deney Düzeni ve Yükleme Düzeni}

Cumhur ve diğ. (2016), diyagonal yükü dolgu duvarlı deney elemanlarına aktarmak için kullandıkları, iç ölçeği $1000 \times 1000$ mm, kare şeklinde olan çelik çerçeveden yararlanılmıştır. Rijit bir düzlem elde etmek için dörtkenarı, iki adet U300 profilinin birleştirilmesiyle çelik bir çerçeve hazırlanmıştır. Bu çerçevenin dört köşesinde mafsallar bulunmaktadır, bu mafsalların ikisinde başlıklar yerleştirilmiştir. Başlıklar yardımıyla diyagonal yükün doğrudan deney elemanına aktarılmasını sağlamıştır. Çerçevenin dört köşesinde mafsallar bulunduğu için duvara uygulanan diyagonal yüke karşı çelik çerçeve direnç göstermeyerek diyagonal yük direk duvara aktarılmıştır. Bu birleşimler, çerçevenin diyagonal yönde yük taşıma kapasitesinin ve rijitliğinin çok sınırlı olmasını sağlamıştır. Deney sırasında çelik çerçeve ve deney elemanı arasındaki temas yüzeyleri duvarın deformasyonuna bağlı olarak değişkenlik göstermiştir. Duvarın artan deformasyonuyla temas yüzeyi de arttığı gözlemlenmiştir. ASTM E519 ise sisteminde temas yüzeyi tüm deney boyunca çerçeve yan uzunluğun \%12,5'i veya duvar uzunluğunun 1/8'i olarak kalmaktadır.

Çelik çerçeve ve deney elemanı arasındaki temas yüzeyi, gerçek sınır koşullarına benzer şekilde deplasmana bağlı olarak duvarın artan deformasyonlarıyla birlikte artmıştır. Aşağıda Şekil 3.25.’te deney mekanizması gösterilmiştir.

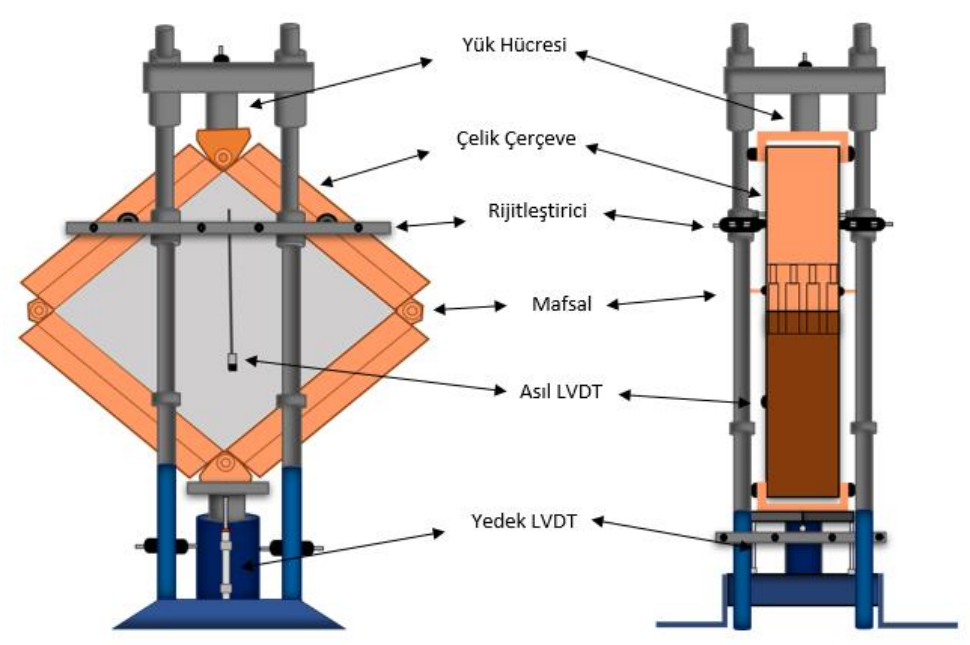

Şekil 3. Deney Sistemi

Deney elemanları ilk önce hasar görmeden çelik kalıp çerçeveye yerleştirilmiş sonrasında deney cihazına yerleştirilmiştir. Deney cihazına yerleştirilirken çelik çerçevenin düzleminin diyagonal eksenden uygulanan yük ile çakışmasını sağlamak için yük hücresinin altında ve hidrolik pistonun üzerinde ortalanmıştır. Çerçevenin deney sırasında hareket etmemesi için yan takviye sistemleri (rijitleştirici) yardımıyla sabitlenip ve deney sırasında düzlem dışı yer değiştirmeler engellemiştir. Yükleme duvarın deplasman kontrollü yükleme ile ve stroke boyu kapasitesine uygun bir şekilde yükleme yapılmıştır, ardından yer değiştirme kontrolü ile gerçekleştirilmiştir. Yük deney elemanının farklı yük seviyelerindeki hasar derecesini gözlemlemiş ve temas yüzeyleri ölçülmüştür. 


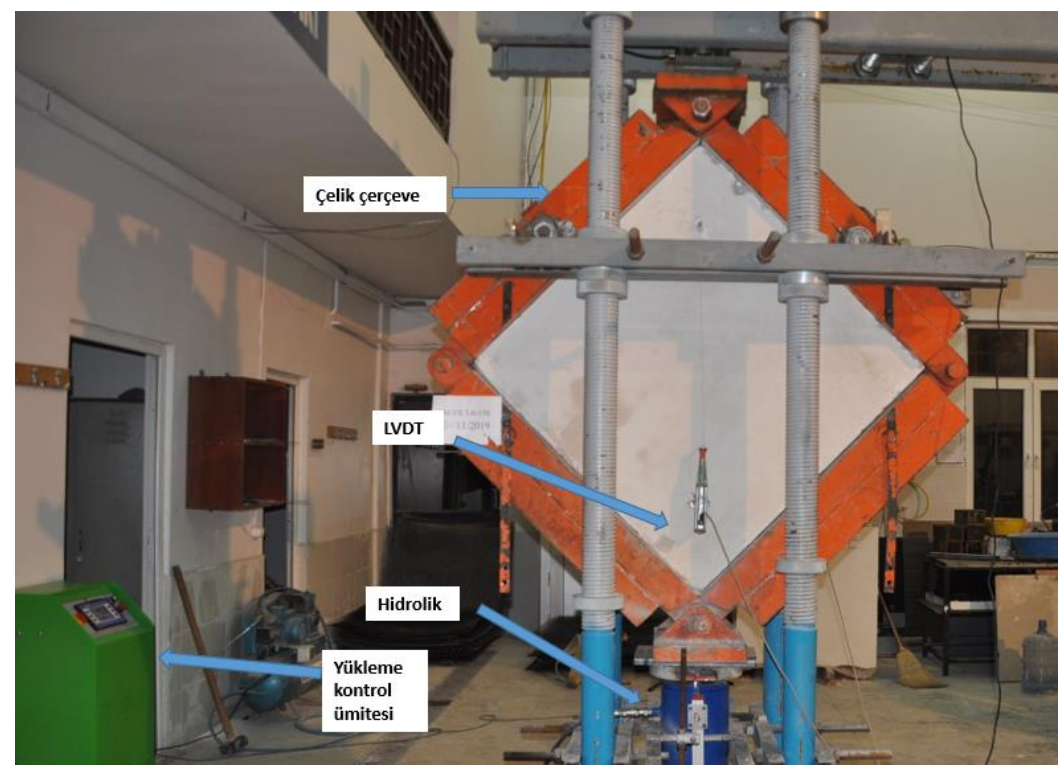

Şekil 4. Deney Sistemin Yükleme Düzeneği

\section{4. Ölçüm Düzeni}

Deney sisteminde uygulanan tekdüze diyagonal yükleme ile deney elemanlarındaki deney sırasında düşey yük doğrultusunda kısalmayı ve yük doğrultusuna dik (yatay doğrultuda) ise uzamayı ölçmek için 0,01 mm hassasiyette toplam 4 LVDT kullanılmıştır. Duvarın ön ve arka yüzeylerin deformasyonları ölçmek için $50 \mathrm{~mm}$ ölçüm yapabilen LVDT kullanılmıştır. Ancak deney esnasında sıvanın çatlaması, LVDT aletlerinin yanlış deformasyon değerleri vermesi nedeniyle, çelik levhanın taban plakasına iki tane 400 mm ölçüm yapabilen LVDT bağlanmıştır. Ölçüm aletlerinin kalibrasyonları her deneyden önce kontrol edilmiştir (Şekil 3.27-30).
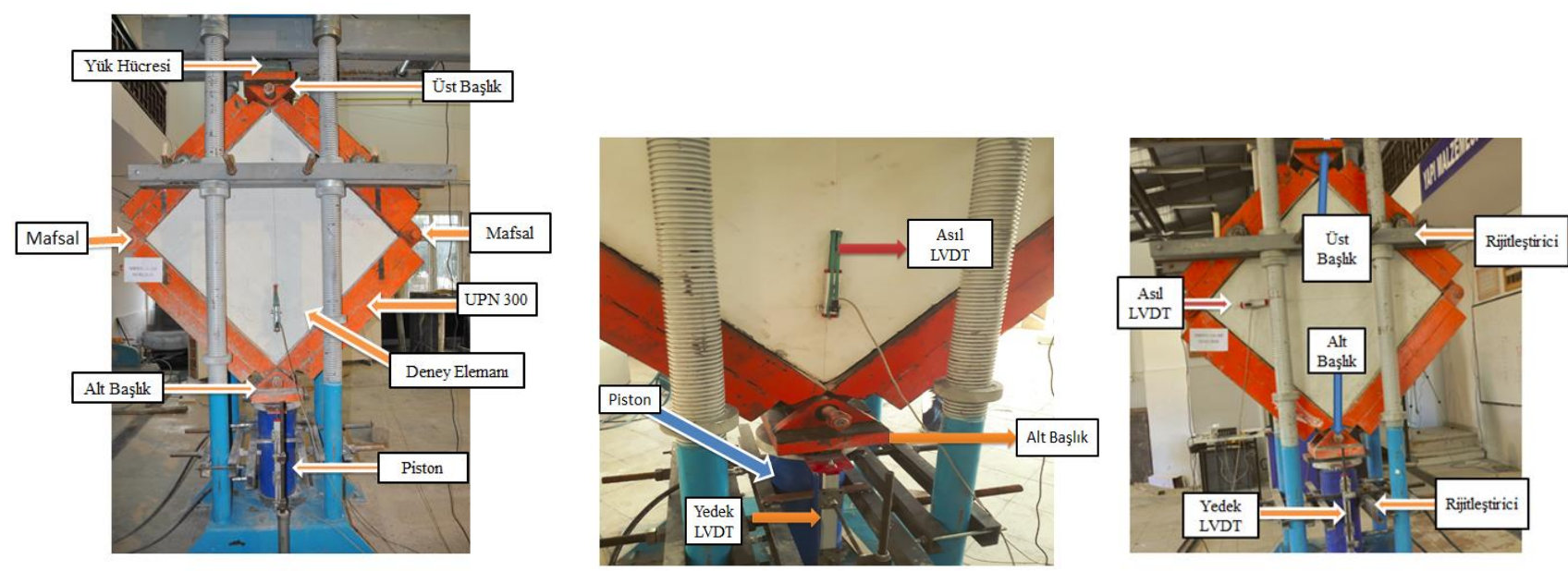

Şekil 5. Deney Elemanı ve Deney Mekanizması

\section{Bulgular}

Bu bölümde, deney elemanları ayrıntılı olarak incelemek amacıyla biri referans dördü güçlendirilmiş deney elemanı olmak üzere toplam 5 adet tam ölçekli deney elemanı diyagonal statik yük altında gösterdikleri performansları gözlemlenerek incelenmiştir. Referans deney elemanı (R), bir adet güçlendirilmiş deneme elemanı (MBW 2,0-200), ve üç adet tuğla duvar üzerine genişletilmiş çelik levhalar ile güçlendirilmiş deney elemanları (MBW 3,0-100, MBW 3,0-150, MBW 3,0-200) ile gösterilen deney elemanlarının deney sonuçları, deney elemanlarının davranışları, deney elemanlarının yük-deplasman grafikleri, deney öncesi ve sonrası resimleri aşağıda sırayla ayrıntılı bir şekilde anlatılmıştır. 
Referans elemanı (R) düşey delikli blok tuğla üzerine herhangi bir güçlendirme işlemi yapılmamış, sadece duvar, üzerinde 20 mm kalınlığında sıva ve üzerinde alçı sıvası uygulanmıştır. Referans deney elemanı güçlendirilmiş deney elemanları ile karşılaştırma amacıyla test edilmiştir. Referans deney elemanı yükleme altında düşey çatlaklar meydana geldikten sonra gevrek bir performans sergileyerek ve tuğlalarının parçalanması nedeniyle ani yük kaybına uğramıştır, Böylece deney sonuna kadar bütünlüğünü koruyamamıştır. Taşıdığı maksimum yük ise $110 \mathrm{kN}$ saptanmıştır.
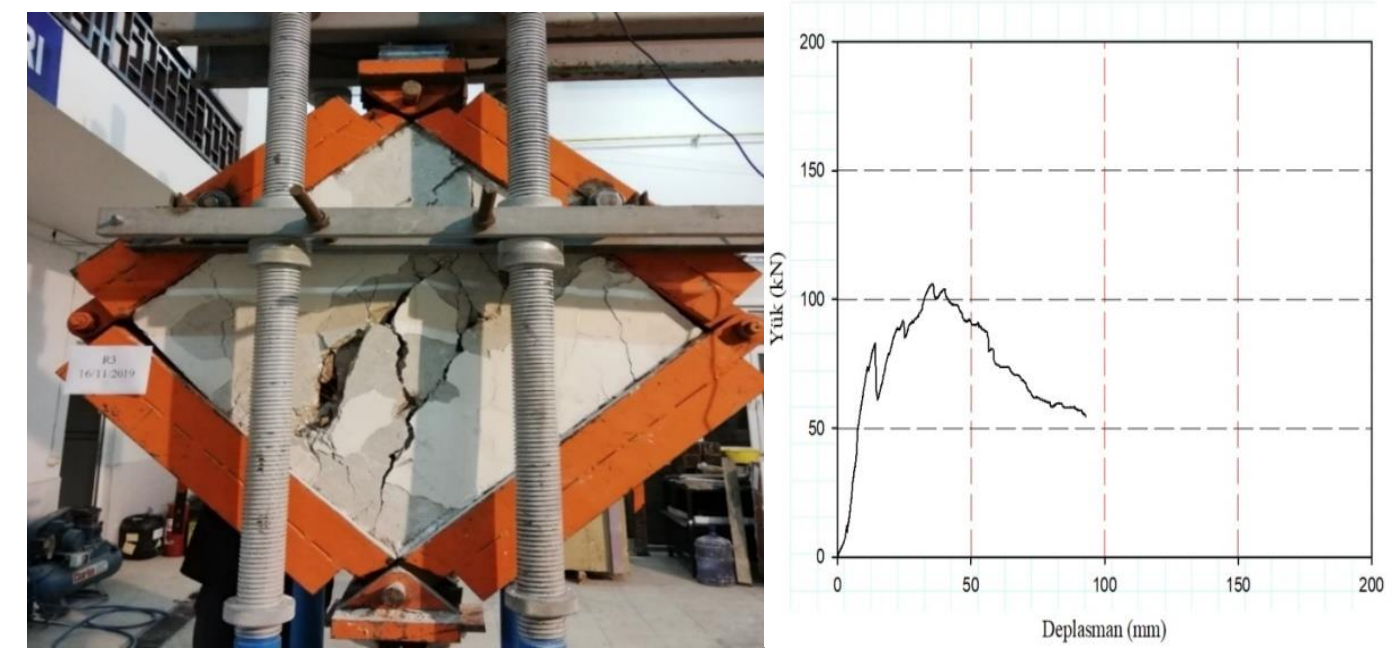

Şekil 6. R Deney Elamanı Yük-Deplasman Grafiği ve Deney Sonrası Hasar Durumu

Güçlendirilmiş deney numunelerinde genişletilmiş çelik levha tuğla duvarın üzerine iki taraflı olacak şekilde yerleştirilerek ankaraj işlemi tamamlandıktan sonra üzerine $20 \mathrm{~mm}$ sıva uygulanmıştır. 28 gün kür işleminden sonra deneye tabi tutulmuştur.

MBW 2,0-200 deney elemanı, 2 mm genişletilmiş çelik levha kalınlığı, $200 \mathrm{~mm}$, bulon aralığına sahip güçlendirilmiş elemandır. Deney sırasında diyagonal çekme çatlakları ve köşelerde ezilmeler meydana gelmiş, köşelerde levhalarda buruşmalar meydana gelmiş ancak herhangi bir bolunda sıyrılmalar ve ayrışmalar oluşmamıştır. Deney elemanı deney sonuna kadar bütünlüğünü korumuştur. MBW 2,0-200 deney elemanının maksimum taşıdığı yük $153 \mathrm{kN}$ ve yaptığı maksimum deplasman 180 mm olarak saptanmıştır.
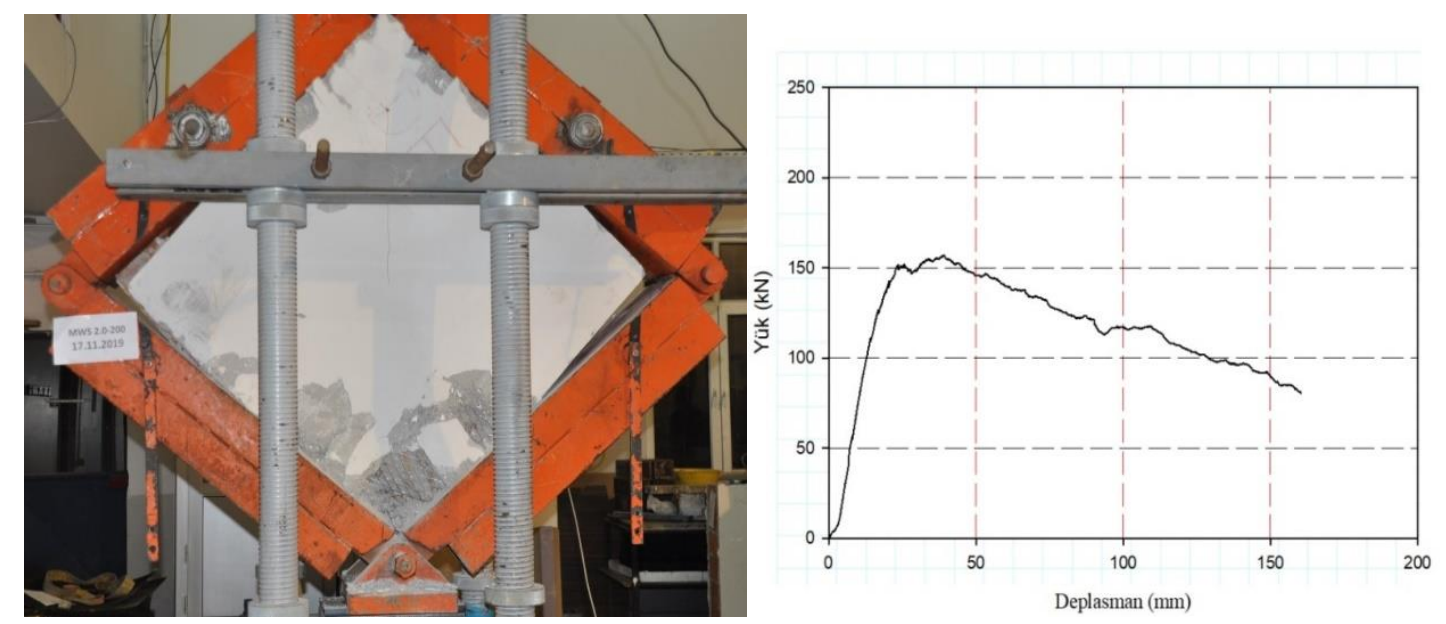

Şekil 7. MBW 2,0-200 Numunesinin Deney Sonrası Hasar Durumu ve Yük-Deplasman Grafiği

MBW 3,0-100 deney elemanı: Bu deney elemanının iki tarafında da kullanılan çelik levha kalınlığı 3,0 mm bulon aralığı 100 mm olarak belirlenmiştir. MBW 3,0-100 deney elemanının maksimum taşıdığı yük 194 kN ve yaptığı maksimum deplasman strok boyunun sonuna gelindiğinden dolayı $240 \mathrm{~mm}$ olarak saptanmıştır. 

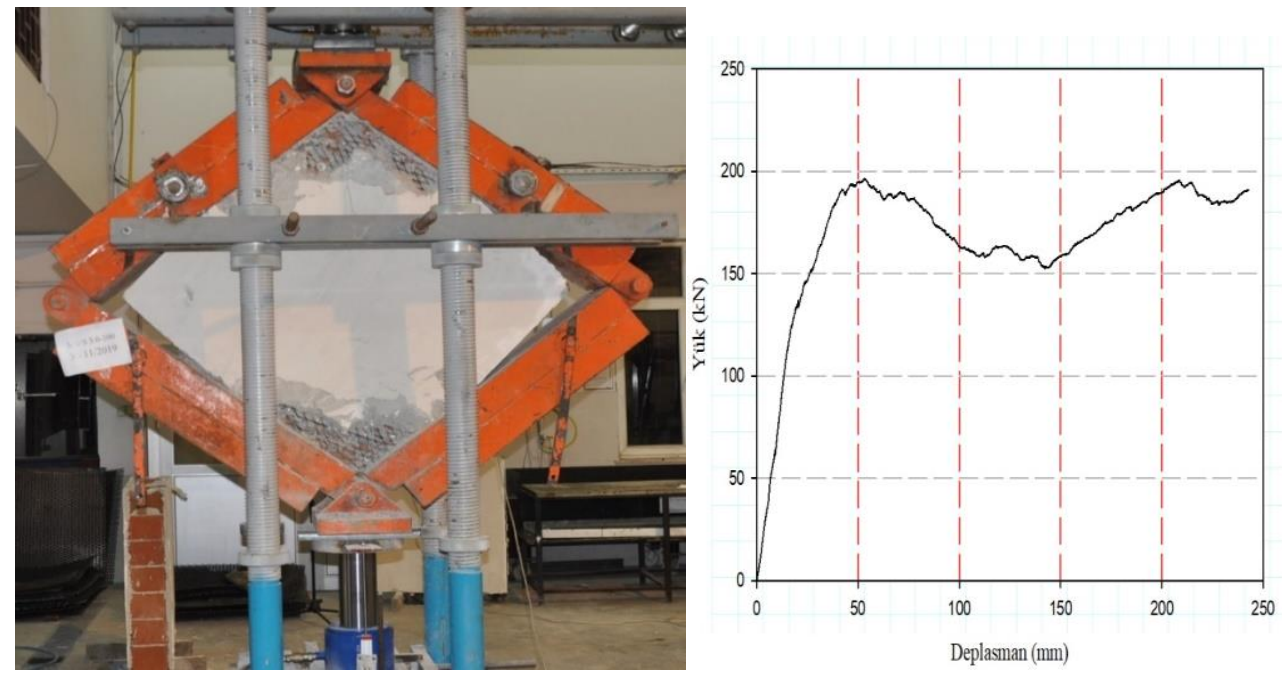

Şekil 8. MBWS 2,0-200 Numunesinin Deney Sonrası Hasar Durumu ve Yük-Deplasman Grafiği

MBW 3,0-150 deney elemanı: Bu deney elemanının iki tarafında da kullanılan çelik levha kalınlığı 3,0 mm bulon aralığı $150 \mathrm{~mm}$ olarak belirlenmiştir. MBW 3,0-150 deney elemanının maksimum taşıdığı yük $246 \mathrm{kN}$ ve yaptığı maksimum deplasman strok boyunun sonuna gelindiğinden dolayı $240 \mathrm{~mm}$ olarak saptanmıştır.
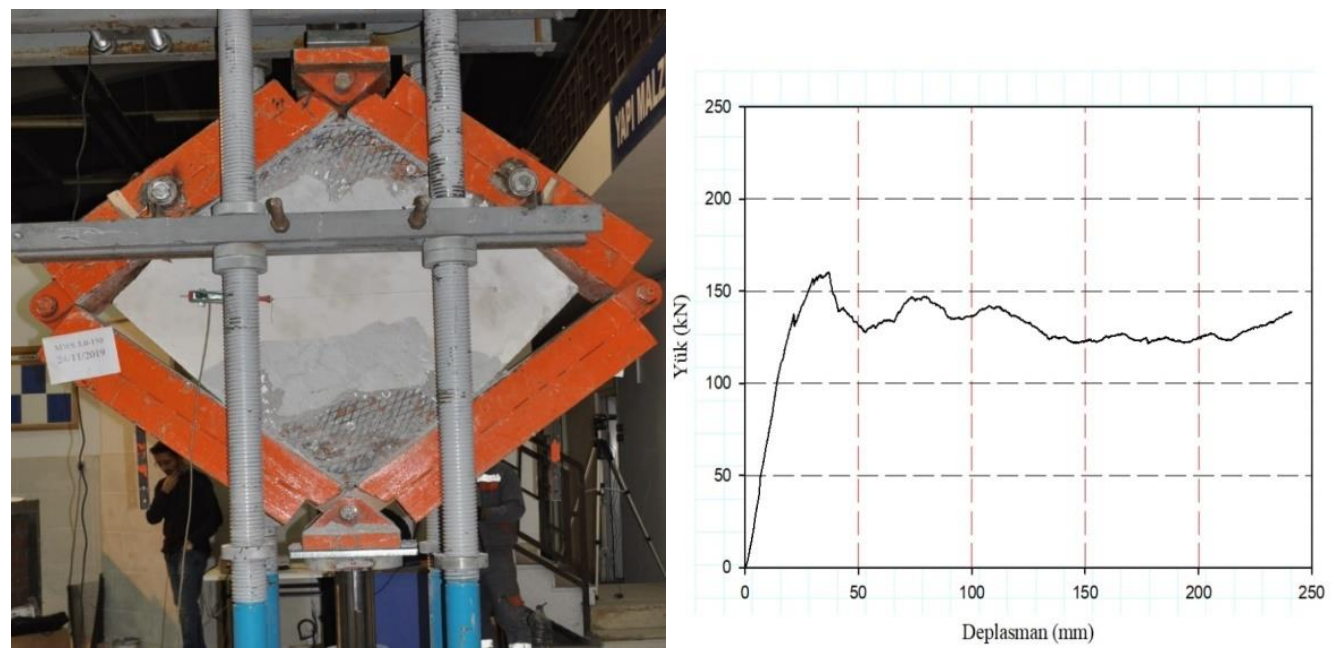

Şekil 9. MBW 3,0-150 Numunesinin Deney Sonrası Hasar Durumu ve Yük-Deplasman Grafiği

MBW 3,0-200 deney elemanı: Bu deney elemanının iki tarafında da kullanılan çelik levha kalınlığı 3,0 mm bulon aralığı $150 \mathrm{~mm}$ olarak belirlenmiştir. MBW 3.0-150 deney elemanının maksimum taşıdığı yük $163 \mathrm{kN}$ ve yaptığı maksimum deplasman strok boyunun sonuna gelindiğinden dolayı $240 \mathrm{~mm}$ olarak saptanmıştır.
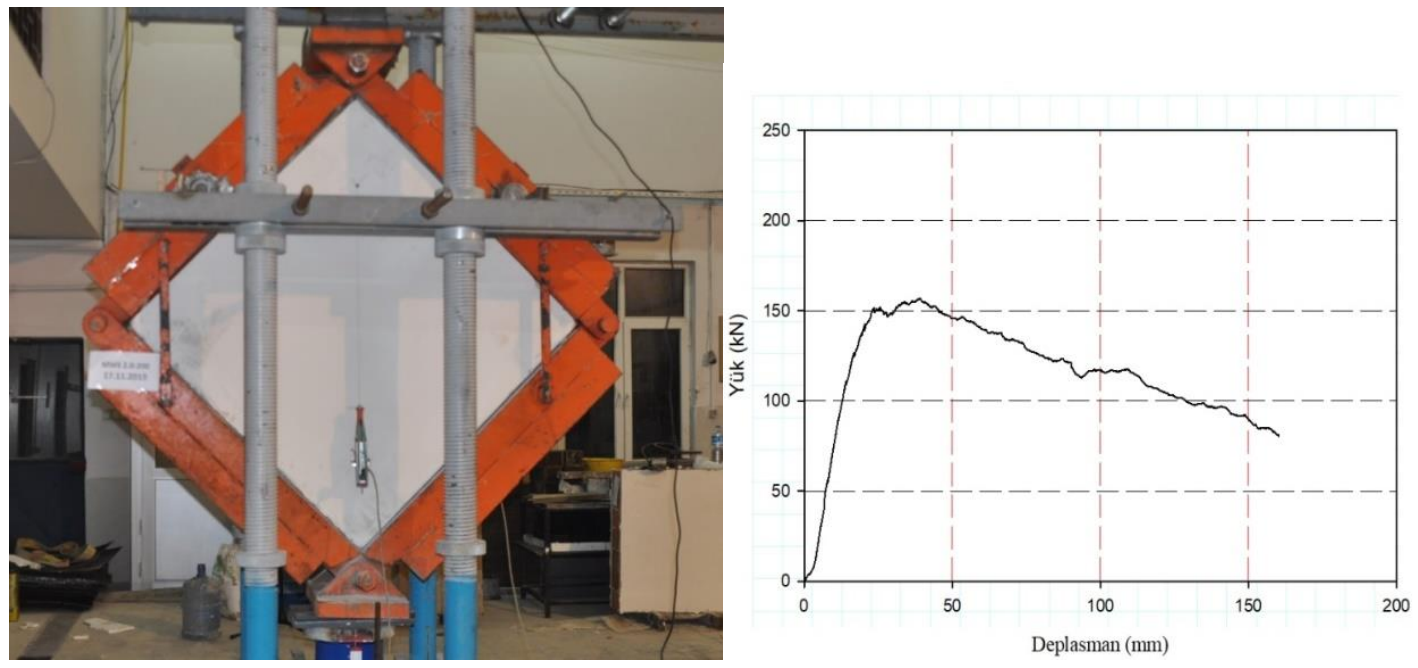

Şekil 10. MBW 3,0-150 Numunesinin Deney Sonrası Hasar Durumu ve Yük-Deplasman Grafiği 


\section{Bulon Aralığının Dayanım ve Davranış Üzerindeki Etkisi}

Levha kalınlı̆̆ eşit, bulon aralı̆̆ı farklı olan deney elemanlarında enerji dönüştürme kapasitesi değerinde bulon aralığı azaldıkça artış görülmektedir. Örnek olarak bulon aralığının 200 mm'den 100 mm'ye düşürülmesi sonucunda enerji dönüştürme kapasitesi değerinde \%13'lük bir artış görülmüş̧ür. Bulon aralığının 200 mm'den 150 mm'ye düşürülmesinde ise $\% 9,2^{\prime}$ lik bir düşüş meydana gelmiştir. Aynı bulon aralığına sahip MBW2,0-200 ve MBW 3,0-200 deney elemanlarında ise levha kalınlığı $3 \mathrm{~mm}$ olan deney elemanın enerji dönüş̧ürme kapasitesi 1,2 kat fazla çıkmıştır.

Bulon aralığının başlangıç rijitlik değeri üzerinde belirgin bir etkisi yoktur. Bulon aralı̆̆ı azaldıkça aynı levha kalınlığa sahip deney elemanlarında rijitlik değerinde artış meydana gelmiş̧tir. Buda bulon aralığının rijitliğe etkisi olduğunu göstermektedir.

Bulon aralığının davranış ve dayanım üzerindeki etkisini incelemek için, yük-deplasman ve enerji-deplasman eğrileri çizilmiştir. Üç adet numunede bulon aralığı dışındaki tüm değişkenleri sabit tutulmuş ve bu numuneler üzerinde yapılan deneylerden elde edilen sonuçlar, levha kalınlığı farklı olan numuneden elde edilen sonuçlarla ve referans elemanından (R) elde edilen sonuçlarla karşılaştırılmıştır. Aşağıda Şekil 10-11'de yük-deplasman ve enerji-deplasman grafikleri verilmiştir.

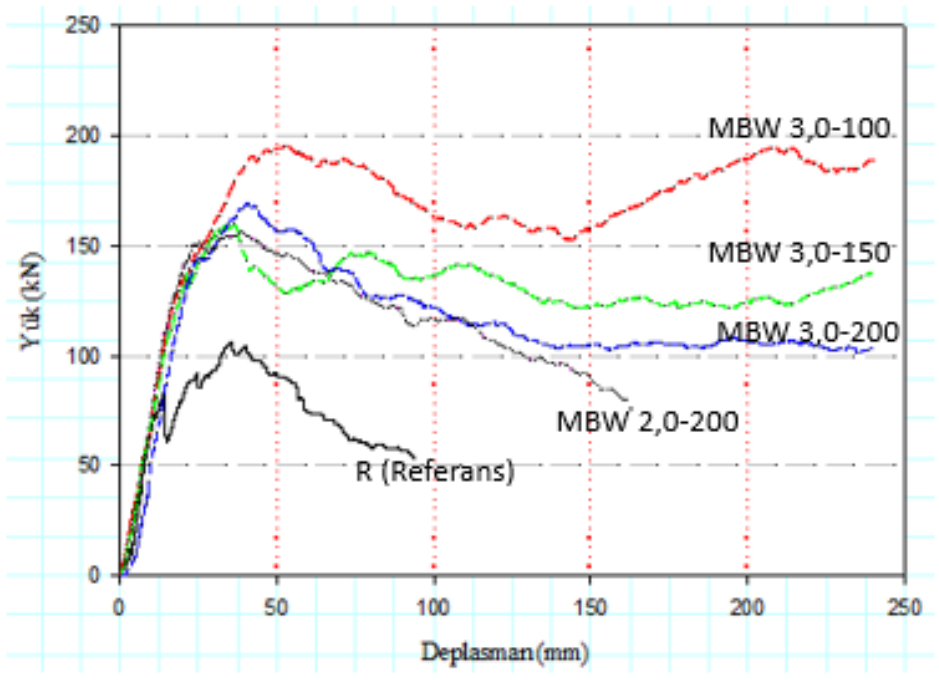

Şekil 11. Tüm Deney Numunelerin Karşıllaştırmalı Yük-Deplasman Eğrileri

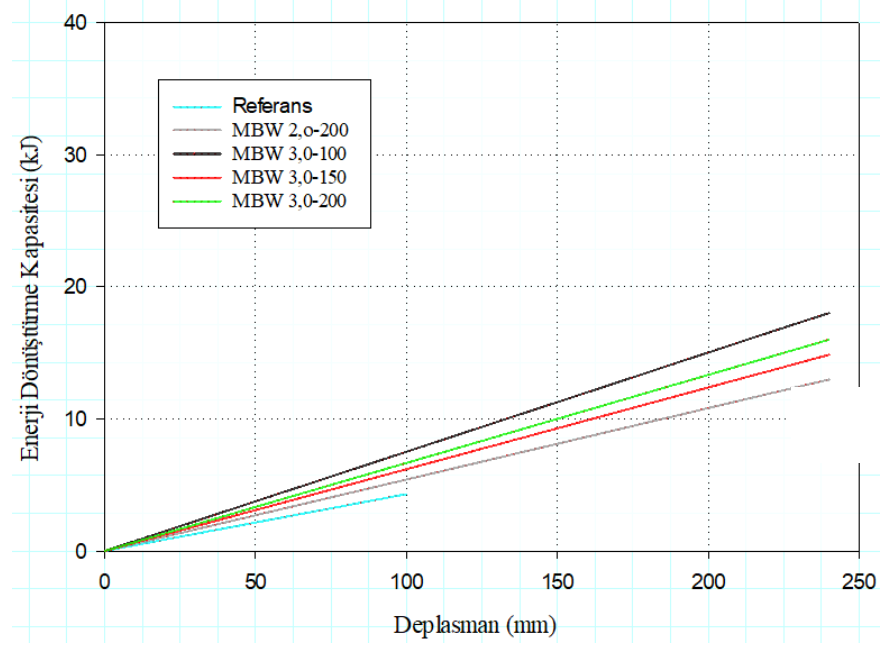

Şekil 11. Tüm Deney Numunelerin Karşılaştırmalı Enerji-Deplasman Grafikleri

\section{Sonuç ve Öneri}

Bu çalışma kapsamında; biri referans, 4 adet güçlendirilmiş eleman olmak üzere toplam 5 adet deney numuneleri hazırlanmıştır. Hazırlanan tüm deney elemanları diyagonal statik yükleme altında test edilmiştir. Yapılan deneylerin sonucunda, genişletilmiş çelik levha güçlendirme elemanlarının bulonlarda akma meydana gelene kadar kompozit bir malzeme olarak davrandığı görülmüştür. Ayrıca, güçlendirilmiş deney elemanlarının yük taşıma kapasitelerinde artış görülmüş ve deney elamanlarının deney sonuna kadar bütünlüklerini korudukları tespit edilmiştir. Bunların yanı sıra; güçlendirilmiş tuğla duvarların, rijitlik, süneklik, enerji dönüştürme kapasitelerinde ve kayma gerilmesi değerlerinde yüksek artışlar sağlanmış olup duvarların davranışlarının iyileştirildiği belirlenmiştir. 
Sonuç olarak çalışmamızdan elde edilen önemli bulgular şu şekilde özetlenebilir. Deney numunelerinde $3 \mathrm{~mm}$ kalınlığındaki genişletilmiş çelik levhalarla yapılan güçlendirme uygulaması sıradan bir işçilikle gerçekleştirilmiş olup, güçlendirme tekniğinin avantajları ve ne kadar kullanılışlı olduğu araştırılmıştır.

Çalışma sonucunda, yığma yapıların düşey yüklere karşı güçlendirilmesi için geliştirilen, genişletilmiş çelik levhalar kullanılması yönteminin oldukça başarılı olduğu görülmüştür. Sıvanmış düşey delikli tuğla yığma duvarların her iki yüzüne genişletilmiş çelik levhalar bulonlar yardımıyla bağlanarak duvar numuneleri güçlendirilmiştir Deneylerin sonucunda; elemanların yük taşıma kapasitesinin, dayanımının, sünekliğinin ve rijitliğinin arttığı görülmüştür.

a. Güçlendirilmiş deney elemanlarının tümü referans numune ile kıyaslanmıştır. Açıklığı en fazla olan bulon aralığına sahip deney elemanının dahi referans deney elemanına göre daha sünek davrandığı gözlenmiştir.

b. Levha kalınlığı eşit, bulon aralı̆̆ı farklı deney elemanlarında bulon aralığı azaldıkça taşıma gücünün arttığı gözlenmiş̧ir.

c. Bulon aralığı eşit, levha kalınlığı farklı olan deney numuneleri incelendiğinde, süneklik, rijitlik, taşıma gücü ve kayma gerilmesi üzerinde kullanılan genişletilmiş çelik levha kalınlığının etkisi olduğu görülmüştür.

d. Deney elemanlarının ön yüzeylerine bağlanan ve birim kısalmalarını ölçen $50 \mathrm{~mm}$ kapasitesi olan LVDT incelendiğinde, güçlendirilmiş deney elemanlarının referans deney elemanına göre birim kısalma oranlarının daha yüksek oldukları gözlenmiştir.

e. Deneyde kullanılan çelik çerçevenin duvarla olan temas yüzeyleri \% $50(50 \mathrm{~cm})$ kadar çıtıı̆ı saptanmıştır.

f. Referans deney elemanın orta yüzeyinde gerçekleşen çatlamalar, özellikle düşey boyunca büyük çatlağın oluşmasından sonra ani yük kaybı meydana gelmiştir.

g. Güçlendirilmiş deney elemanlarında ise referans deney elemanın aksine, orta yüzeylerinde önemli çatlaklar meydana gelmemiş ve ani yük kaybı da yaşanmamıştır.

h. Güçlendirmede kullanılan çelik levha ve bulonlar vasıtasıyla duvarda sargılama özelliği sağlanmış ve deney boyunca herhangi bir ayrışma ve sıyrılma yaşanmamıştır.

\section{Teşekkür}

Bu araştırma, Sakarya Üniversitesi Bilimsel Araştırma Projeleri (BAP) Komisyonu Başkanlığı (Proje No: 2019-7-24-30) tarafindan desteklenmiştir.

\section{Kaynakça}

ASTM E519/E519M-10. (2010). Standard test method for diagonal tension (shear) in masonry assemblages. American Society for Testing and Materials, West Conshohocken, Pennsylvania, U.S.A.

Bahçekapıll, S. (2003). Mevcut betonarme yapıların depreme karşı güvenliğini belirleme yöntemleri. Sakarya Üniversitesi, Fen Bilimleri Enstitüsü, İnşaat Mühendisliği Anabilim Dalı, Yüksek Lisans Tezi.

DBYBHY, (2018). Deprem bölgelerinde yapılacak binalar hakkında yönetmelik. Bayındırlık ve İskan Bakanlığı, Ankara, Türkiye.

Cumhur, A. (2016). Tuğla dolgu duvarların genişletilmiş çelik levhalar ile güçlendirilmesi. Sakarya Üniversitesi, Fen Bilimleri Enstitüsü, İnşaat Mühendisliği Anabilim Dalı, Doktora Tezi.

Cumhur, A., Altundal, A., Kalkan, İ., Aykaç, S. (2016). Behaviour of brick infill walls strengthened with expanded steel plates. Bulletin of Earthquake Engineering 14.11 (2016): 3231-3258.

FEMA, F. (1998). FEMA 306. (1998). Evaluation of earthquake damaged concrete and masonry wall buildings. Federal Emergency Management Agency, Redwood City, California, U.S.A.

ISO 6892-1, (2016), Metallic materials- Tensile testing - Part 1: Method of test at room temperature.

Najif İ., Robert B. Petersen, ve Mark J.Masia. (2011). Diagonal shear behaviour of unreinforced masonry wallettes strengthened using twisted steel bars. Construction and Building Materials Pages 4386-4393

Özbek, E., (2015). Delikli çelik levhalarla güçlendirilmiş tuğla duvarların çerçeve davranışı üzerindeki etkisi. Gazi Üniversitesi Fen Bilimleri Enstitüsü 176. Doktora Tezi.

Tekeli, H., Akyürek O., Deniz M., Hersat E., Kara N., Tosun U., ve Kaya F. (2014). Betonarme çerçevede dolgu duvarların hasır çelik donatılı sıva ile güçlendirilmesi. Beü Fen Bilimleri Dergisi 